which was changed by the colonial transfers of exotic plants for industrial crops and plantation agriculture (as well as the ravaging of flora and fauna); with the transfers of people, not only of the European sottlers but also of the alien labour whom they imported and who, in many places and with prosont embarrassment, aro now outnumbering the indigenous population; with the geography of disease and with the population explosion.

When we speak to-day of tho great benefits which modern (Western) medical services and modical sciences have conferred on Pacific peoples, it is well to romind ourselves (as the author does) that the most dangerous exports of the Western world wore small-pox, measles, pulmonary diseases, malaria, filariasis, hookworm, loprosy, maybe syphilis and certainly gonorrhœea, which decimated indigenous peoples who had no immunity.

On population distribution and redistribution, the book is less convincing. Australia, with the swarming millions of Asia too close for comfort, is compared with Canada (6 per square mile) and Asian Russia (2 per square mile). By deducting the arid lands and the tropics, Australia has 720.000 romaining out of $2,900,000$ square miles, which gives 14 (whites) per square mile. But there can be argument even about that subtraction. "Unsuitable for settlers" depends on what sort of sottlers and whether lands can be mado suitable. A.fter all, the whole story of man is one of mastering his environment. Nor is it better than a debating point to say that Australia is taking the majority of migrants from some of the most erowded countries on the Earth-Britain with 540 per square mile, compared with India with 293 ; the Netherlands with 839 per square mile, compared with Japan with 610 ; and Italy with 413 per square mile, compared with Indonesia with 139. He makes the point that the 'white policy' of the U.S.S.R. in its Asian territories and the inviting sparseness of Siberia, just north of expanding China, "will require a solution one day": verbum satis sapienti.

$\mathrm{H}_{\Theta}$ has a case, how $\Theta$ vor, for arguing that countries now looking enviously at open spaces might look at their own. Indonesia, with Soekarno clamouring for lebensraum, has a population of 700 per square mile in Java, 70 in Sumatra and 7 in South Borneo. Tho sensible plans operated by the Dutch for resettlement have been conspicuously unsuccessful undor his régime.

This is an invaluable book for those who want to see the imperial past, without romance or recrimination; who want to understand what is behind the crisis headlines and who want to be sonsible about tho future. Rrtchie Calder

\section{TROPICAL METEOROLOGY IN AFRICA}

\section{Tropical Meteorology in Africa}

Proceedings of the Symposium Jointly Sponsored by the World Meteorological Organization and the Munitalp Foundation. Edited by D. J. Bargman. Pp. xv +446 . (Nairobi: Munitalp Foundation, 1960. Available from the World Meteorological Organization, Geneva.) 20 Sw. francs; $33 s .3 d . ; 4.70$ dollars.

W WIILE the Proceedings of a symposium, published an unnecessary record of material which is either ephemeral or already on record elsewhere, this is certainly not true of the Nairobi symposium on tropical meteorology in Africa. Under the joint sponsorship of a United Nations specialized agency and an independent research foundation, tropical meteorologists attended from twentyone African countries, as well as from Belgium, Britain, France, Germany, Spain and the United States; and the record of proceedings, despite a few typographical and linguistic lapses, reflects part of a unique background of collective professional experience, much of which has still to reach the literature.

There were a number of authoritative and valuabls reviews of the problems and methods of tropical meteorology in gencral, but special attention was naturally directed to new findings specifically concerning Africa. These may perhaps complement some of the earlier post-war progress in tropical meteorology, which was based predominantly on data 'climatically insular' rather than continental. In particular, while fully recognizing the continuing need for better observational cover, the symposium unanimously accorded a high priority to further work on new synoptic models. This need was also the main theme of the 1964 presidential address to the Royal Meteorological Society, which posed, as the central problem of meteorological analysis in general, the fact "that the rapidly increasing amount of meteorological data which is being collected will not be properly put to use-indeed part of it may not be used. at all-unless an adequate system exists to collate and present it in a form which can be readily understood and digested". At the Nairobi symposium, special interest centred on the progress in this respect reported by Johnson and Mörth, establishing in eastern Africa relationships between equatorial weather and typical flow patterns in the middle troposphere; and visiting meteorologists were particularly impressed to see these ideas already incorporated into present-day forecasting practice. Furthermore, this work, utilizing the additional upperair data which became available during the International Geophysical Year (and incidentally supported by one of the few Colonial Development and Welfare schemes in tropical meteorology), demonstrated for the first time a series of systematic relationships betwcen winds and contours of isobaric surfaces in the equatorial belt. This is a long-standing problem of the general circulation. to which attention was also directed by the work of Cochemé in the same region.

Another subject on which potentially elassical results were first presented in detail at this symposium was the energy-balance of tropical land surfaces. Pereira and McCulloch described catchment-area experiments in which continuous direct measurements were made of all the more important factors in the heat and water balance over complete valleys, varying in extent from sixteen hectares to eight square kilometres. From these results, together with heat-flux analyses over bare soil and water-use studies of grasses and crops, measured values were presented for a representative samplo of land-surface conditions, ranging from the warm and semiarid plains of central Tanganyika at an altitude of $1,000 \mathrm{~m}$ to bamboo mist-forest up to $3,600 \mathrm{~m}$ in the Aberdare mountains of Kenya. The importance of these data, as a contribution not only to applied meteorology but also to the physical basis of the science, was emphasized by Prof. Flohn - whose presentation of his own analyses of climatological data from Africa and the adjoining oceans, undertaken in such a manner as to provide significant information on synoptic-scale phenomena, was strongly approved by synoptic meteorologists present.

Space does not permit mention of other significant lines of work reported, on meteorology and on its applications to African problems. A final point, which is perhaps of some interest in relation to the organization of such symposia in general, is the effectiveness with which technical discussion was stimulated by a relevant and extensive travel programme, including, for example. the agricultural resettlement schemes of the Aberdare catchments; the Murchison Falls, with their fantastic associated wild-life probably still much as Samuel Baker saw it a hundred years ago; and the Owen Falls dam, where the scale of the combined uncertainties both of the total rainfall over Lake Victoria, and of evaporation losses from its surface, is still of the same order of magnitude as the resulting flow of the Nile. R. C. RAINEy 